\title{
Entrepreneurship in the Colombia-Ecuador Border Integration Zone in the Post-Conflict Setting
}

\author{
Martha Lida Solarte Solarte ${ }^{1 *}$, Claudia Magali Solarte Solarte ${ }^{2}$ \\ ${ }^{1}$ Full-Time Research Professor, Corporación Universitaria Minuto de Dios - UNIMINUTO, Pasto, Colombia \\ ${ }^{2}$ Full-Time Research Professor at Universidad CESMAG, Pasto, Colombia
}

Received: 01/06/2020

Accepted: 22/07/2020

Published: 20/09/2020

\begin{abstract}
This article is about the urgency of creating and proposing development alternatives to reintegrate former members who belonged to the Revolutionary Armed Forces of Colombia (FARC) into civilian life. On the occasion of the signing of the peace treaty between this group and the Colombian government in 2016; also for the victims and territories with the highest incidence of the conflict in the Colombia-Ecuador border. The general objective was to analyze the forms of productive entrepreneurship as facilitators in the process of reintegration into the post-agreement period in Colombia taking into account the successful experiences in the creation of Ecuadorian companies. The methodology used a quantitative approach, analytical empirical method and descriptive research. The tools to collect information were a survey and an interview; with a sample of 128 reinserted FARC members and 47 Ecuadorian social and solidarity-based economy organizations. The results come from reinserted FARC members located in the Municipality of Tallambí (Colombia) and the social and solidarity-based economy organizations in the Canton of Carchi (Ecuador). The information obtained about directing and entrepreneurship policies came from the two governments (Ecuador and Colombia), and models of creating companies according to the characteristics found. It can be concluded that the majority of reinserted people are youngsters between the ages of 26 and 30, that is, in a productive age, willing to train and assume entrepreneurship proposals to continue their reintegration process and improve their quality of life. This can be possible with the help of the two governments, the social institutions and the international community.
\end{abstract}

Keywords: Peace treaty, Social and solidarity based economy, Entrepreneurship, Colombia-Ecuador border, Post-conflict, Reinserted people

\section{Introduction}

In the Department of Nariño (Colombia), many of the municipalities have been affected by the armed conflict, which is still present throughout the country. To solve this problem, the National Government, after a four-year period of peace talks with the Revolutionary Armed Forces of Colombia (FARC), decided to sign the peace treaty in 2016. This is known as the post-conflict period in which all agreed points must be implemented. Among these points, it was agreed to create territorial training and reincorporation spaces known as espacios territoriales de capacitación y reincorporación (ETCRs) to gather former guerrilla combatants. The armed conflict generated a large number of casualties and internally displaced people, resulting in the instability of the territories in terms of economy, social life by, environmental damage and loss of cultural identity. Many young people who lack of education, spare time, job opportunities, health services and, in general, living in extremely poverty were recruited by armed groups with ideals of change. However, this proved to be more complex and turned into drug trafficking, kidnapping, extortion and other crimes that overwhelmed the ideals of the guerrillas. The Rio Guáitara region, near to Colombia's border with Ecuador, was immersed in this conflict because there are several problems such as high levels of unemployment, informal employment, a subsistence economy, lack of access

Corresponding author: Martha Lida Solarte Solarte, Fulltime Research Professor, Corporación Universitaria Minuto de Dios - UNIMINUTO, Pasto, Colombia. E-mail: msolartesol@uniminuto.edu.co routes and, in general, inadequate infrastructure with little innovation, poor associative models and poor training for work. The conditions mentioned above is the context a person faces in the process of reintegration, once he leaves the illegal armed group; a context in which there are a lot of difficulties, social inequality and economic needs with a permanent threat of illegal activity such as drug trafficking and emerging illegal gangs. Therefore, signing the peace treaty presents a significant challenge for both regions and the youth and adult population in the process of reintegration because they will need help from the government and public and private entities focused on education and income generation to promote productive entrepreneurship and improve their quality of life. Thus, the canton of Carchi in Ecuador shows a new model based on the inclusion of social organizations, which come together to carry out production, consumption and service activities as the basis of a new entrepreneurship model in the social and solidarity-based economy sector, this model includes both Ecuadorian and Colombian migrants who settled on their territory as victims of the armed conflict. This research is carried out is in the Municipality of Cumbal, Tallambí, located in the south of the Department of Nariño, near Ecuador borderline. According to the Development Plan in the Municipality of Cumbal 2016-2019, 93\% belongs to the Pastos indigenous group; the remaining $7 \%$ is the mestizo community. According to the census carried out by the Departamento Administrativo Nacional de Estadística [1-3], there is a total population of 37,635 inhabitants, 8,428 live in the urban area and 29,207 in the rural area. This population is $50.08 \%$ male and $49.9 \%$ female. The economy is based on agriculture, both people in the process of reintegration and the 
local indigenous population work on crops to produce Solanum quitoense, known as lulo, which is marketed in Ecuador. The Tallambí community builds consensus decisionmaking and this is an example of a process of reintegration and reconciliation. It has not been easy at first, but former guerrilla members have gradually approached and hope in the future no longer talking about community and reintegration; all of them are brothers, inhabitants in the same territory and teach a lesson about respect, tolerance and fulfill their word [4].

Moreover, agencies such as the United Nations (UN) in Colombia and the United Nations Food and Agriculture Organization (FAO), the Nariño Governorate, the Servicio Nacional de Aprendizaje (SENA), the Agency for Reincorporation and Standardization, the Office of the United Nations High Commissioner for Refugees and the Mission to Support the Peace Process in Colombia (MAPP) of the Organization of American States (OAS) assisted in the formulation of life plans, technical training, funding, education and the strengthening of the cabildo internal regulations. Members of the FARC guerrilla group who have arrived to the training and reincorporation place in Tallambí are between 13 and 17 years old and 56\% are over 17 years. As a total, $92 \%$ deserters are men. Likewise, these people have a low level of schooling, in this way Pinto Borrego, Vergara Ballén \& Lahuerta Percipiano in 2002 emphasize that $84 \%$ have not completed primary school, $8 \%$ is illiterate and the remaining $8 \%$ studied only at seventh grade. Besides, people from nearby countries such as Ecuador and Venezuela, who live near the border areas, had also been recruited into this insurgent group. Therefore, these countries have also been feeling the impact of Colombia's armed conflict with an increase in poverty, insecurity and informal economy [5].

In order to support this study, there are the following report: Emprendimiento productivo como facilitador para la reinserción en el postconflicto en Colombia: un análisis desde la experiencia de otros países, by Pérez Castillo. It shows the importance of productive entrepreneurship for reintegration, taking into account age, gender, schooling to use their skills, abilities and attitudes in projects that contribute to the region development. It highlights the importance of adjusting educational and entrepreneurship programs to the participants' needs, to encourage former guerrilla members to move into civilian life and work as peace ambassadors [6]. In Cortés Sánchez's study, J. D. [6] entitled: Emprendimiento, instituciones y construcción de paz, the overall objective is to improve the execution of sustainable entrepreneurship projects that aim for peace-building and regional development, through institutions that promote the creation of companies for these purposes and to cooperate with the national and historical context from the educational centers. Another research is the one entitled: Factores motivacionales de la población en proceso de reintegración social y económica para su ingreso y permanencia en el sistema educativo, área metropolitana de Risaralda durante el año 2010: estudio cualitativo realizado con participantes del proceso de reintegración en el área metropolitana de Risaralda by Farfán Orozco, M. B. and Alzate Pineda, C. M. [7], showing a description of the motivational factors that affect the population in the reintegration process in terms of linkage and permanence in the educational system. In addition, to achieve a successful process of reintegration the conceptual foundations of reintegration program consist of the change of deserters into autonomous citizens, the strengthening of social, economic and cultural aspects and the promotion of national coexistence and reconciliation. Regarding the situation of the social and solidarity-based economy organizations, their work dynamics have become interesting, as they favor their production in a region that has been classified as deprived by the pendulum effect on business, because of the changes in the currency exchange rate. Therefore, the objective of this research was to analyze the productive entrepreneurship as a means to facilitate the post-conflict reintegration process in Colombia taking as an example the successful experience in the creation of Ecuadorian companies.

\section{Methodology}

As for the research, a quantitative approach was implemented along with a reference framework based on quantifiable and measurable unit of analysis, and the implementation of statistical instruments. These instruments sought for economic aspects, culture appreciation and social relationships in the social and solidarity-based economy in the canton of Carchi (Ecuador). In the same way, an analytical empirical method was applied, since the data collected comes from the community. The type of research was descriptive, analyzing people's characteristics, properties and profiles in order to measure and evaluate data based on several concepts that constituted the research variables. Thus, the demobilized people's needs were analyzed to propose alternative solutions within the entrepreneurship framework. Two surveys were implemented to collect information: one to the reintegration groups and the other one to the social and solidarity-based organizations in the canton of Carchi, and a semi-structured interview with government representatives such as the governor of Nariño, Ipiales mayor, demobilization and reintegration office and the Servicio Nacional de Aprendizaje (SENA), leaders of the social and solidarity-based organizations, focus groups and demobilized people in the community.

The population study consisted of demobilized people living in the Colombia-Ecuador border, in the village of Tallambí. Moreover, it was taken into account the information coming from the social and solidarity-based organizations in the canton of Carchi, Ecuador. The research sample was taken from 128 ex-combatants from the Territorial Training and Reincorporation, located in the village of Tallambí. As for the social and solidarity-based organizations sample, 194 registered organizations registered in the cadaster of Superintendence of Popular and Solidarity Economy of Ecuador; this was confronted with a mapping that established a reliability of this record at around $60 \%$, that is, the information of the cadaster does not break down closed associations, so a high number of them were shown. Thus, a $92 \%$ was considered, along with an acceptance rate of 0.85 , and a sampling error of $8 \%$. The equation (1) showed a sample of 47 unit of analysis.

$n=\frac{k^{2} \mathrm{pqN}}{e^{2}(\mathrm{~N}-1)+K^{2} \mathrm{pq}}$

where $\mathrm{N}$ is population size that was 194 ,

$\mathrm{K}$ is confidence level $=92 \%$,

$\mathrm{e}$ is sampling error $=8 \%$,

$\mathrm{p}$ is acceptance rate $=0.85$,

$\mathrm{q}$ is non acceptance rate $=0.15$,

and $\mathrm{n}$ is sample.

The sample obtained was divided by canton according to the number of social and solidarity-based organizations existent in the region. As shown in the following table (Table 1). 
Table 1: Sample distribution by canton

\begin{tabular}{clcl}
\hline Province & Canton & Percentage distribution & Social and solidarity-based organizations \\
\hline \multirow{5}{*}{ Carchi } & Tulcán & 32 & 15 \\
& Bolívar & 13 & 6 \\
& Espejo & 11 & 5 \\
& Mira & 11 & 5 \\
& Montufar & 28 & 13 \\
& San Pedro de Huaca & 6 & 3 \\
& Total Carchi & 100 & 47 \\
\hline
\end{tabular}

Source: cadester of the Superintendence of Popular and Solidarity Economy of Ecuador

\section{Results}

\subsection{Characterization of demobilized people living in}

\section{Tallambí (demographic information)}

Most of the demobilized people belong to the male gender. Most of the demobilized people are young and within the economically active population. Much of the demobilized people live in domestic partnership. In the rural areas the strata level is 0 . Most of demobilized people have a secondary school, $65 \%$, which can be corroborated in the table 6 . The type of continuing education that they would most like to access demobilized people is the technical level. Most of demobilized people come from the Nariño department located in southern Colombia .Most of demobilized people have families of 5 people, father, mother and three children.

Table 2: Gender

\begin{tabular}{llll}
\hline Female & $\%$ & Male & $\%$ \\
\hline 47 & 37 & 81 & 63 \\
\hline
\end{tabular}

Table 3: Age

\begin{tabular}{llllll}
\hline Age range & $\%$ & Age range & $\%$ & Age range & $\%$ \\
\hline Less than 20 & 7 & 36 to 40 years & 12 & 56 to 60 \\
21 to 25 & 18 & 41 to 45 years & 10 & More than 61 \\
26 to 30 & 32 & 46 to 50 years & 2 & \\
31 to 35 & 17 & 51 to 55 years & 7 & \\
\hline
\end{tabular}

Table 4: Marital status

\begin{tabular}{llllll}
\hline Marital status & $\%$ & Marital status & $\%$ & Marital status & $\%$ \\
\hline Married & 8 & Domestic partnership & 71 & Separated & 0 \\
Single & 17 & Divorced & 1 & widow(er) & 3 \\
\hline
\end{tabular}

Table 5: Social strata

\begin{tabular}{ll}
\hline Strata level & $\%$ \\
\hline 0 & 100 \\
\hline
\end{tabular}

Table 6: Educational level

\begin{tabular}{llllll}
\hline Level & $\%$ & Level & $\%$ & Level & $\%$ \\
\hline Elementary school & 31 & Technical level & 4 & Undergraduate & 0 \\
Secondary school & 65 & Technological level & 0 & Postgraduate & 0 \\
\hline
\end{tabular}

Table 7: Continuing Education

\begin{tabular}{llllll}
\hline Type of course & $\%$ & Type of training & $\%$ & Type of training & $\%$ \\
\hline Short course & 35 & Certificate & 1 & Technological & 5 \\
Seminar & 12 & Technical level & 34 & level Undergraduate & 13 \\
\hline
\end{tabular}

Table 8: Birthplace

\begin{tabular}{llllll}
\hline Birthplace & $\%$ & Birthplace & $\%$ & Birthplace & $\%$ \\
\hline Nariño & 93 & Putumayo & 2 & Chocó \\
Cauca & 3 & Valle & 1 & & \\
\hline
\end{tabular}

Table 9: Number of children

\begin{tabular}{llllll}
\hline Number of children & $\%$ & Number of children & $\%$ & Number of children & $\%$ \\
\hline None & 8 & 2 children & 22 & $\begin{array}{l}\text { More than } 3 \\
\text { children }\end{array}$ \\
1 child & 19 & 3 children & 28 & & 23 \\
\hline
\end{tabular}




\subsection{Socio-economic information}

The $48 \%$ demobilized people own their own home and fully paid. Of the demobilized people the one who contributes the most to household income is the father, although it is observed that the mother also works and contributes. $47 \%$ of the demobilized people are farming. The activities in which the most the demobilized people participate are sports with $52 \%$ (Table 13). The activities in which the demobilized people ones participate the most are working community work and meetings with $44 \%$ each (Table 14). It is important that $96 \%$ of the demobilized people if they are affiliated with the health social security system. $100 \%$ of the reinstated belong to the subsidized regime (Table 15). $98 \%$ of the demobilized people earn less than a minimum wage (Table 16). $80 \%$ of the demobilized people would like to create a company in the primary economic activity (agriculture and livestock, fishing, mining), because as described above, the region lends itself to this type of activity (Table 17). The type of economic activity that the demobilized people prefer is agriculture with $71 \%$ (Table 18).

\section{Discussion}

One part of this research was aimed at characterizing demobilized people who are in the process of reintegration. This aspect is important to make a diagnosis of their current situation, which is necessary to guide the public policies that strengthen the different areas in which these people have to manage in accordance with the government of Colombia and the national and international organizations; their sociocultural context, work and political participation.

Table 10: Housing tenure

\begin{tabular}{|c|c|c|c|c|c|}
\hline enure & $\%$ & enure & $\%$ & Housing tenure & $\%$ \\
\hline Renting & 18 & Owner & 48 & Other type & 2 \\
\hline Paying for a house & 5 & $\begin{array}{l}\text { Living in a relative's house } \\
\text { without paying rent }\end{array}$ & 21 & $\begin{array}{l}\text { Living in someone's house } \\
\text { without paying rent }\end{array}$ & 6 \\
\hline
\end{tabular}

Table 11: Household expenses

\begin{tabular}{llllll}
\hline Person in charge & $\%$ & Person in charge & $\%$ & Person in charge & $\%$ \\
\hline Father & 43 & Yourselves & 18 & Husband & 2 \\
Mother & 29 & Children & 5 & Other & 3 \\
\hline
\end{tabular}

Table 12: Time devoted to activities

\begin{tabular}{llllll}
\hline Activity & $\%$ & Activity & $\%$ & Activity & $\%$ \\
\hline Employee & 22 & Looking for a job & 2 & Farming & 47 \\
Working and studying & 3 & Housework & 9 & Freelancer & 17 \\
\hline
\end{tabular}

Table 13: Participation in activities

\begin{tabular}{llll}
\hline Activity & $\%$ & Activity & $\%$ \\
\hline Sports & 52 & Religious & 20 \\
Artistic & 28 & Other & 0 \\
\hline
\end{tabular}

Table 14: Social and family activities

\begin{tabular}{llllll}
\hline Activity & $\%$ & Activity & $\%$ & Activity & $\%$ \\
\hline Community work & 44 & Sporting events & 9 & Special days & 1 \\
Meetings & 44 & Festivities & 2 & & \\
\hline
\end{tabular}

Table 15: Pension and health insurance

\begin{tabular}{llll}
\hline Affiliated & $\%$ & Scheme & $\%$ \\
\hline Yes & 96 & Contributory & 0 \\
No & 4 & Subsidized & 100 \\
\hline
\end{tabular}

Table 16: Income based on Colombia's minimum wage (SMLV)

\begin{tabular}{lcll}
\hline Income & $\%$ & Income & $\%$ \\
\hline Less than a minimum wage & 98 & 2 minimum wages & 1 \\
Equal to a minimum wage & 1 & Over 2 minimum wages & 0 \\
\hline
\end{tabular}

Table 17: Time devoted according to economic activity

\begin{tabular}{llll}
\hline Economic activity & $\%$ & Economic activity & $\%$ \\
\hline Primary (agriculture and livestock, fishing, mining) & 80 & Tertiary (service, commerce, & construction, health, education) \\
Secondary (industry, manufacturing) & 14 & & 6 \\
\hline
\end{tabular}

Table 18: Time devoted according to economic activity

\begin{tabular}{llll}
\hline Economic activity & $\%$ & Economic activity & $\%$ \\
\hline Agriculture & 71 & Service & 4 \\
Commerce & 17 & Industry & 1 \\
Livestock & 7 & & \\
\hline
\end{tabular}


Regarding the reintegration process, Marcial López who is the Cabildo governor in Tallambí, [8] expresses: [The advantages are many, we have already known State entities and from the different countries that come and visit us. And we hope that the upcoming projects will benefit us all - I have made a commitment with them and has to be fulfilled]. Thus, according to the information collected, it was found that this population is mostly young people. This population is considered as productive, so that it demands sources of employment or they can create their own company. According to the Global Entrepreneurship Monitor (GEM, 2013), nearly six million five hundred thousand Colombian adults, between 18 and 64, are starting their own business. The Total earlystage Entrepreneurial Activity (TEA) an index analysis by GEM, measures the business initiatives between 0 and 3.5 years in which those are maintained in the market based on the population of 18-64 years in a country. This is a decisive period for most entrepreneurs because there is greater dynamism, innovation and job creation in this age group. Regarding education, most of demobilized people have secondary education. Through the time, people with this educational level are the ones who report the highest number of entrepreneurship in Colombia according to the National Development Plan 2010-2014 (in Spanish Plan Nacional de Desarrollo 2010-2014). Taking into account the objective of this research, this is advantageous because the high school provides a number of tools to learn and train and have a better job performance, also people con continue their studies to be more skillful in their area because entrepreneurial actions should not only be the product of empirical experience or by necessity. It has been said that the basis of development are education and qualified people. According to the GEM report, regarding the TEA index, the $30.5 \%$ relates to universityeducated persons who have created their own business, this may indicate that the remaining percentage refers to people with primary and secondary education. The following table presents the education coverage in the region that was studied.

In addition, a third of the demobilized people have taken short-term or technical courses related to crop care, heavy equipment handling, pig farming, cooperation, systems and the Peace agents training course. In the Development Plan of the Municipality of Cumbal 2016-2019 (in Spanish Plan de Desarrollo del Municipio de Cumbal 2016-2019), regarding to continuing education, it says:
"La Unidad Municipal de Asistencia Técnica Agropecuaria (UMATA), se ha enfocado en actividades enmarcadas dentro de las necesidades de los sistemas locales de producción. En este sentido, se han planteado estrategias de transferencia de tecnología y asistencia técnica que puedan ser viables y al mismo tiempo adopTABLE por los productores" (p. 149)

[The Unidad Municipal de Asistencia Técnica Agropecuaria (UMATA) has focused on activities considering the needs of local production systems. In this regard, technology transfer and technical assistance strategies have been put forward, these strategies can be feasible and at the same time adoptable by producers.] (p. 149) [8]. While twothirds of participants have a relationship with a partner or live in a domestic partnership and a minimum number have married because of their living circumstances, about a quarter must support two, three or more children, being the father or mother the ones who are in charge of taking care of them and home. This situation can be positive for productive entrepreneurship and the families can be motivated to organize their life project, insure family income and how they generate it. Also, this can help create a company and also family businesses [9]. Moreover, it is important to mention that most of the former guerrilla members who have been located in the border area, were born in the Department of Nariño. Thus, it can be assumed that they prefer their homeland and close relatives. There is no doubt that by their experience in these communities, they have incorporated a set of customs and these guide their lives, as can be seen in fig. 1, in which cultural preservation is an important aspect of their cultural identity, and respect is one of the values they want to prevail, (see fig. 2). Similarly, the demobilized people have a major participation in sports, artistic and community activities such as community work and meetings, these activities are necessarily made in teamwork fostering creativity, innovation and proposition. Their deep-rooted traditions, culture, values, beliefs and community participation are important assets to carry out sustainable and long-lasting projects. Varela [10] comments:

"Al hablar de la cultura de un grupo, una región, una nación o una empresa, se hace referencia al conjunto de valores, creencias, convicciones, ideas, respuestas, reacciones, expresiones, sentimientos y competencias que ese grupo ha adquirido a lo largo de las experiencias que forman parte de su vida" (p. 169).

Table 19: Education coverage in Cumbal, 2015

\begin{tabular}{|c|c|c|c|c|c|c|c|c|c|c|c|c|}
\hline \multirow{3}{*}{ 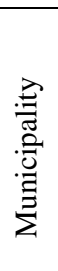 } & \multirow{3}{*}{ 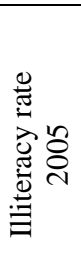 } & \multicolumn{11}{|c|}{ Education coverage -2015} \\
\hline & & \multicolumn{2}{|c|}{ Preschool } & \multicolumn{3}{|c|}{ Primary school } & \multicolumn{3}{|c|}{ Secondary school } & \multicolumn{3}{|c|}{ High school } \\
\hline & & 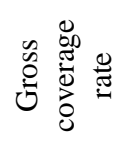 & 乙 & 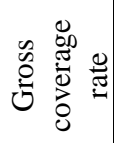 & 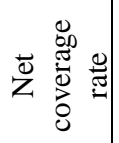 & 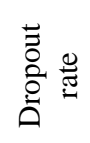 & 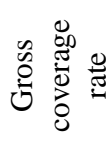 & 乙 & 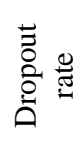 & 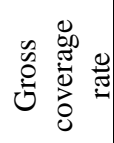 & 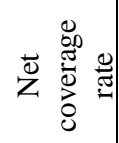 & 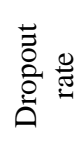 \\
\hline $\begin{array}{l}\bar{\Xi} \\
\text { Eี } \\
\Xi\end{array}$ & $\begin{array}{l}\stackrel{0}{o} \\
\stackrel{8}{=}\end{array}$ & $\begin{array}{l}0 \\
\infty \\
0 \\
0 \\
0\end{array}$ & $\begin{array}{l}\stackrel{0}{2} \\
\infty \\
\infty \\
\text { तु }\end{array}$ & $\begin{array}{l}\frac{0}{0} \\
\dot{0}\end{array}$ & 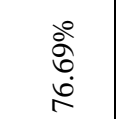 & $\frac{8}{8}$ & $\frac{\stackrel{\circ}{n}}{\stackrel{\infty}{\infty}}$ & 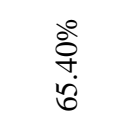 & $\begin{array}{l}\stackrel{\circ}{0} \\
\infty \\
0\end{array}$ & $\frac{8}{n}$ & 官 & $\begin{array}{l}\infty 0 \\
\stackrel{0}{=}\end{array}$ \\
\hline
\end{tabular}

Taken from: Plan de Desarrollo Departamental: Nariño corazón del mundo 2016-2019, p. 436 
[The municipality currently has a qualitative housing deficit of $51.1 \%$ and 1.3 in quantitative deficit. Especially in vulnerable indigenous families in Panan, Chiles, Mayasquer and Gran Cumbal (...) there are still families that do not have their own house, living in poor conditions, overcrowding, houses without electricity and poTABLE water causing and spreading disease, especially in children. In this sector, a housing project will be managed according to the available resources]. (p. 72). In terms of work, about half of demobilized people have engaged in agriculture, a quarter is employees and the other quarter do the housework, work as a freelancer or they are students. One of the productive initiatives they have started on their own is the construction of garage for pig farming; they have a machine to produce bricks and a fish pond to grow bream. With this it can be said that a majority is gaining work experience, which is advantageous to propose entrepreneurship programs, creation of individual or associative companies or a popular solidarity economy. According to the development plan Nariño Corazón del Mundo 2016 to 2019, the productive, agro-industrial and commercial development program states:

"Teniendo en cuenta que en Nariño la mayor parte de los productores agropecuarios son de pequeños productores, con este subprograma se busca desarrollar capacidades productivas y agroindustriales para fortalecer el emprendimiento, la comercialización y la generación de mayores ingresos (...) Conforme a lo anterior, se busca promover el desarrollo de procesos de capacitación al talento humano, de asociatividad, producción y comercialización, además de fomentar proyectos de producción limpia e incentivar la organización de productores con la cultura de producción agroecológica."

[Considering that the majority of agricultural producers in Nariño are small producers, the purpose of this program is to develop productive and agro-industrial strategies to strengthen entrepreneurship, marketing and higher incomes (...) In accordance with the aforementioned, it seeks to promote the development of training process, associativity, production and marketing, as well as promoting cleaner production projects and fostering agro-ecological practices]. Some of the difficulties demobilized have when looking for a job are related to lack of knowledge, shortages of vacancies, little experience and a low level of education (see Figure 3). The Development Plan in the Municipality of Cumbal 2016-2019 says:

"Existen altos índices de desempleo rural que afecta principalmente a la población indígena y campesina de los resguardos de Panán, Chiles, Mayasquer y Cumbal" (p. 150).

["There are high rates of unemployment in the rural area that affect both the indigenous and peasant people in Panán, Chiles, Mayasquer and Cumbal" (p. 150)]. In the same document, there are some strategies to solve this problem, some of them are: (a) local Development Strategy. The first step is to know about the strengths of the local economy and establish action areas to encourage business development and generate employment along with the public and private actors; (b) institutionalize the public-private dialogue. It is necessary to create municipal competitiveness committees and monitor its implementation with the private sector; and (c) local governments must be responsible and inclusive. The municipality is not only responsible for services and infrastructure; it must also play a pro-active role in generating a good business environment.

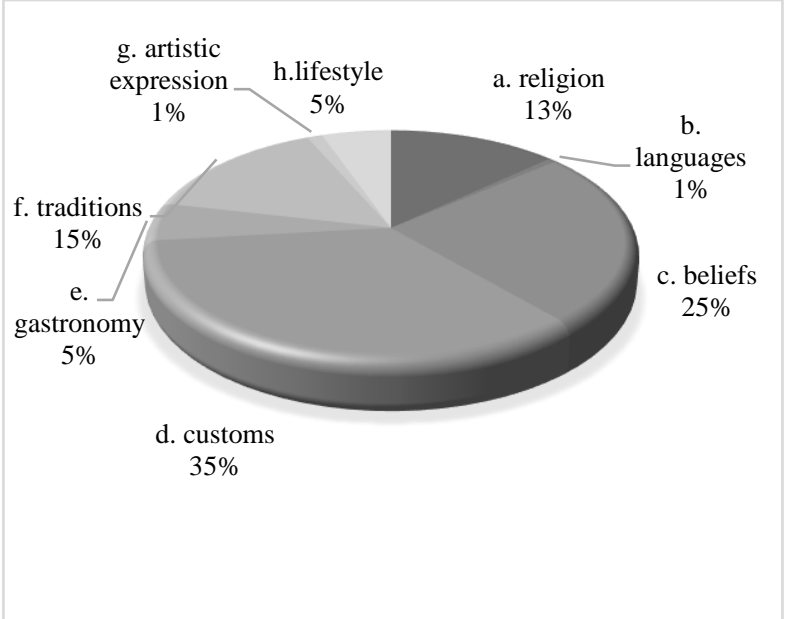

Figure 1: The most important aspect regarding cultural identity

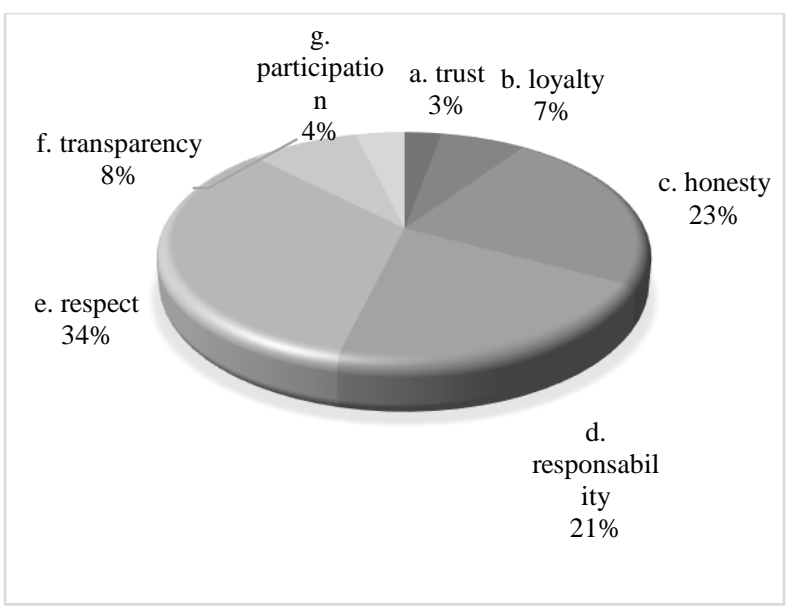

Figure 2: The most important moral values

[When talking about the culture of a group, region, nation, or company, it makes reference to a set of values, beliefs, beliefs, ideas, responses, reactions, expressions, feelings, and competencies that a group has acquired over their lifetime experiences] (p. 169). Regarding the deep-rooted traditions, the family is involved, and for the participants this is something relevant to develop solidarity, while some of them have been able to own a house, about a half live in a house without paying rent as long as they can be employed or create teir own or cooperative business. Thus, solidarity is a strong motivation to continue in the process of reintegration into society, even though most of them are engaged in different productive activities and their minimum wages are lower. Therefore, they need to do other jobs to increase their incomes and get a better quality of life for their family. Respecting to household in the Municipality of Cumbal, the Development Plan expresses:

"El municipio actualmente presenta un déficit de vivienda cualitativo del $51.1 \%$ y el 1.3 en déficit cuantitativo. Especialmente en familias vulnerables de los resguardos indigenas de Panan, Chiles, Mayasquer y el Gran Cumbal (...) aún siguen existiendo familias que no cuentan con una vivienda propia, viviendas en malas condiciones, hacinamiento, viviendas sin los servicios básicos lo que genera que prevalezcan enfermedades especialmente en los niños y niñas menores. En este sector se gestionará proyectos de vivienda de interés social, tanto del municipio como del cabildo, de acuerdo a los recursos con que se cuenta" (p. 72). 


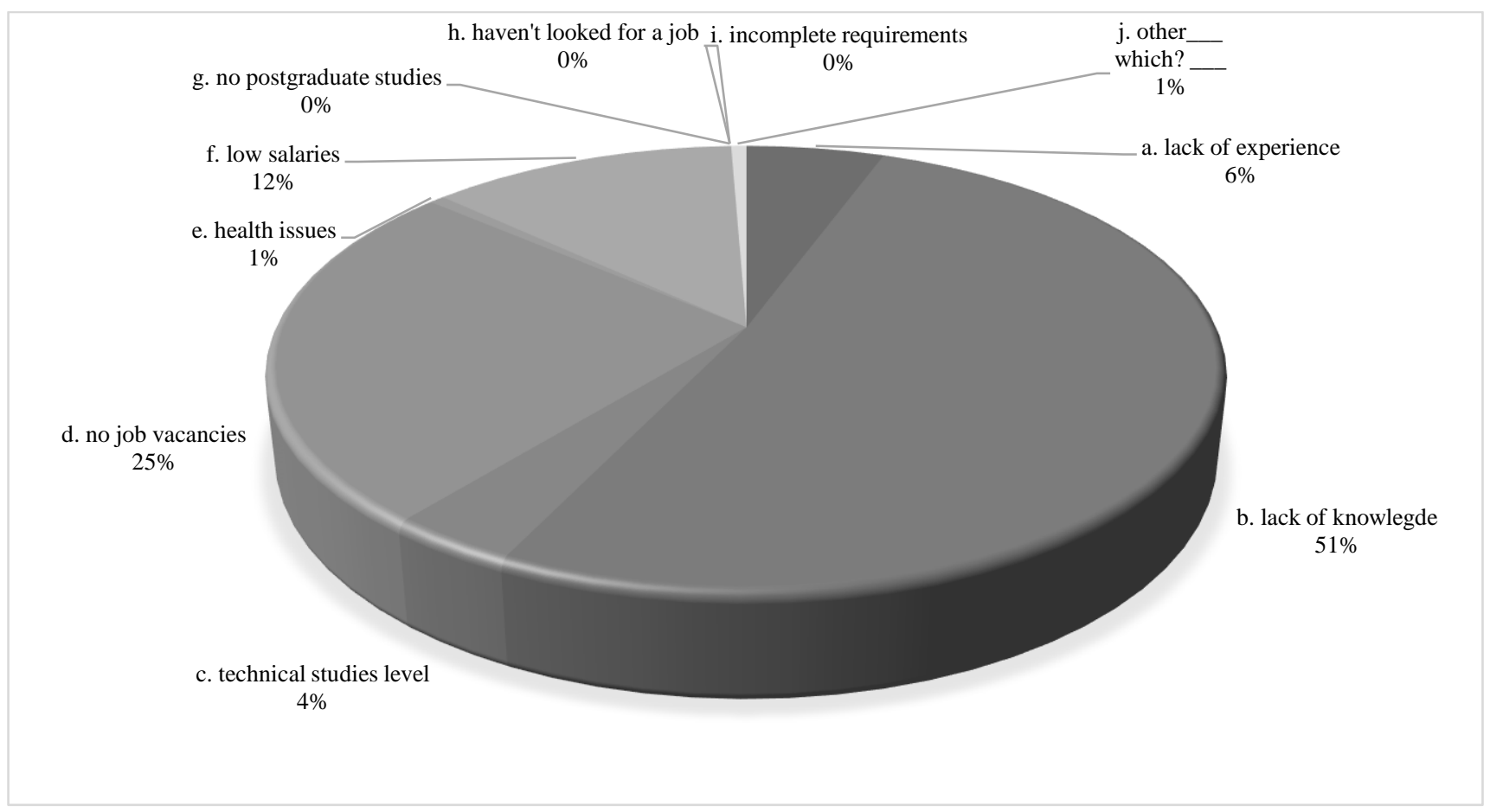

Figure 3: Job search difficulties

Competitiveness programs should promote transparency, tax management, financial administration and participatory budgeting (p. 141).

Considering unemployment as one problem in the community, this research sought for opportunities to give the demobilized people entrepreneurship training, in which the 99\% agreed (see Fig 4); of course, this is in accordance with the Development Plan of the Municipality of Cumbal 20162019, which states that:

"En educación debemos atender los sectores de calidad, cobertura y eficiencia, invirtiendo los recursos y haciendo que se ejecuten proyectos de este programa" (p. 161).

[In education we must pay attention to quality, coverage and efficiency, investing the available resources and executing the projects for this program] (p. 161). In the same way, the interest of demobilized people in creating their own business and being entrepreneurs is high (see fig 5). In addition, the Development Plan of the Municipality of Cumbal 2016-2019, presents some entrepreneurship alternatives that include demobilized people who have settled down in the village of Tallambí:

"Nos pondremos como meta constituir como mínimo cuatro medianas empresas en los cuatro años de administración, las mismas que deberán generar una buena cantidad de empleos directos e indirectos cada una, aprovechando las potencialidades de nuestra gente, los recursos públicos del Municipio, los Cabildos, el Departamento y la Nación entre otros" (p. 257).

[Our purpose is to establish at least four medium-sized enterprises in a four-year period, these ones will have to offer both direct and indirect jobs, taking advantage of our people's potential, the public resources that belongs to the
Municipality, the Cabildos, the Department and Colombia, among others] (p. 257).

One of the guarantees that demobilized people have accessed is their affiliation to the subsidized health insurance (see Fig 6). The objective is to create conditions that ensure the population well-being, which starts from health promotion and disease prevention, through individual and collective actions that guarantee access to the service. [in the analysis carried out in the municipality of Cumbal in October 2015, 31,029 users affiliated with different health promoting entities (E.P.S) were found in the municipality (...) most of them had the subsidized scheme. The E.P.S. operates through contracts, providing health care at the indigenous health providing institution (I.P.S) from Cumbal and the Statal social organizations (E.S.E). Cumbal Hospital] (p. 48).

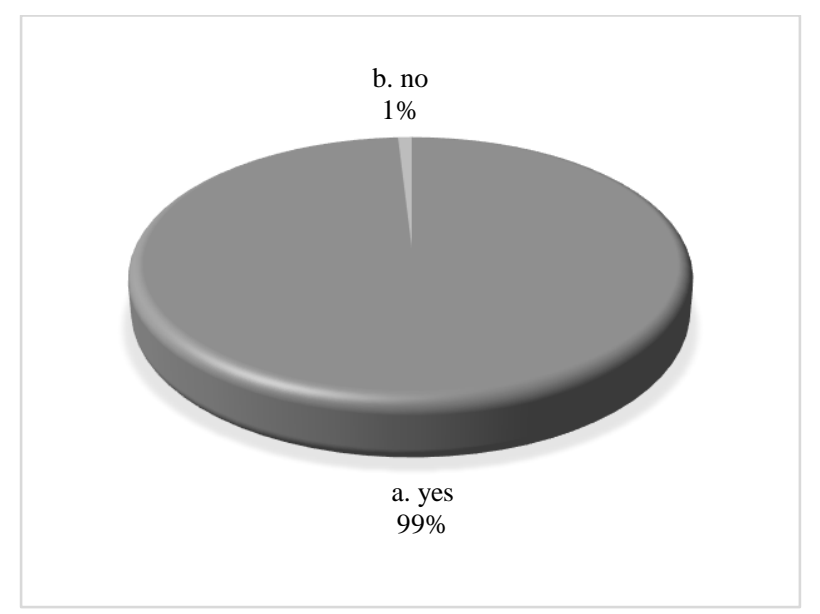

Figure 4: Demobilized people's interest in entrepreneurship training 


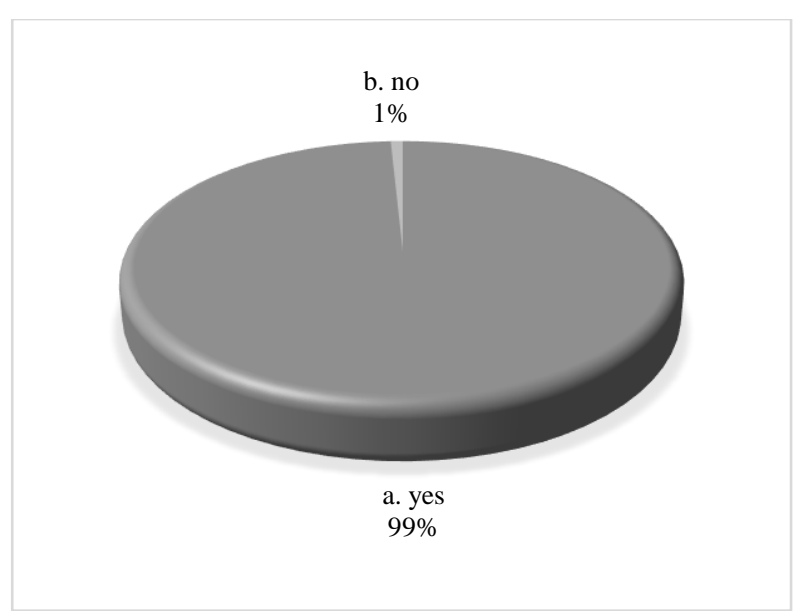

Figure 5: Demobilized people who want to create or take part in a micro-enterprise

Health is a structuring axis for welfare and working conditions in the population. The Plan Decenal de Salud Pública del Departamento de Nariño states: (i) guarantee the right to health according to its function and needs, and (ii) improving the living and health conditions of the population as part of social justice. Finally, in the first part of the research, it is important to note that the majority of demobilized people have been organized into a single, multiactive association, some of the resources mostly come from their own contributions, microcredits and credits (see Figure 7).

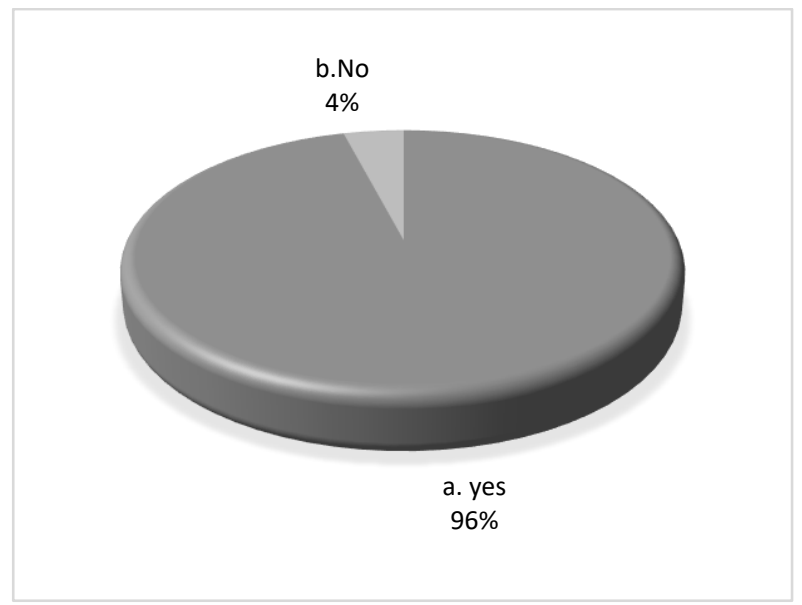

Figure 6: Affiliation to health insurance

The Development Plan of the Municipality of Cumbal 2016-2019 expresses:

"Dentro del análisis realizado del Municipio Cumbal a octubre de 2015, al régimen subsidiado mediante la inspección, vigilancia y control a los actores del sistema general de seguridad social en salud, se encontraron 31.029 usuarios afiliados a diferentes E.P.S presentes en el municipio (...) Estas E.P.S operan por medio de contratos, brindando la atención de servicios de salud en la I.P.S indígena de Cumbal y en la E.S.E Hospital Cumbal". (p. 48).

These resources are reinvested in working capital; equipment purchase and a reward for workers (see Fig 8). This associative model is significant because it forms the basis of community-based organization, participation and coexistence. In addition, people can participate together in productive activities, and they can come to an agreement, they can also be active members in the development of the region and foster tolerance and respect. According to the Colombian Constitution of 1991 , in its $7^{\text {th }}$ article says:

"El Estado reconoce y protege la diversidad étnica y cultural de la Nación colombiana."

[The State recognizes and protects the ethnic and cultural diversity in the Colombian Nation].
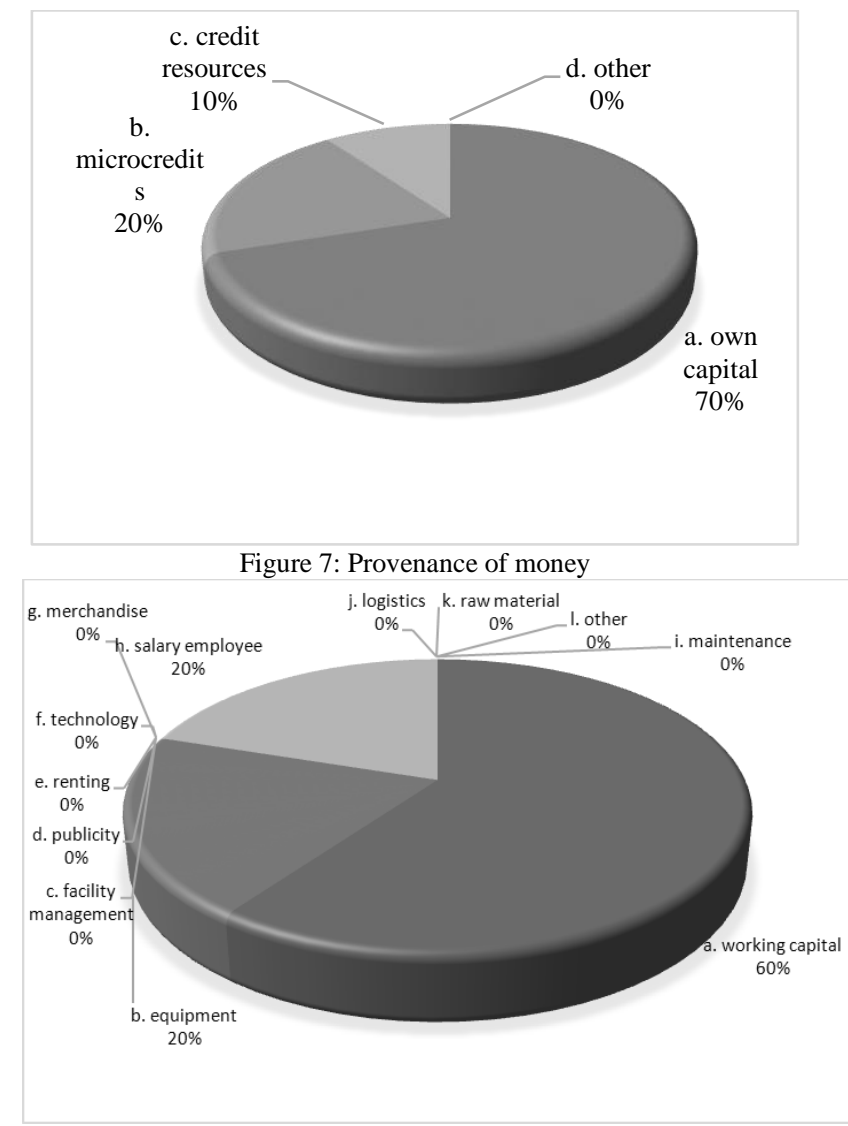

Figure 8: Investments made by the association

\section{Conclusions}

Reintegration is an economic and social process in the post-conflict period in Colombia, a process that will benefit not only the demobilized people by improving their quality of life, but also the development of communities at the local and regional level. Creating a demobilized people database is important because they were part of a rigidly hierarchical community, guided by customs and values which created another viewpoint. Those characteristics must be taken into account as previous knowledge to establish new knowledge and social practices. The sociocultural environment is one of the factors that affect the formation of a business mindset, because it encourages people to be skillful in entrepreneurship whether for industrial independence or for a good job performance. This means that the regional economy must react as quickly as the new approaches in entrepreneurship and technological advances appear. The creation of territorial training and reintegration spaces (ETCRs) in the Tallambí community establish a starting point to think about several forms of development because the peace treaty poses significant challenges and the proposals coming from international organizations. In regard to social organization and productivity, they can be innovative. However, the 
process of reintegration is not easy to carry out, both inhabitants and demobilized people have gradually approached to build consensus through dialogue and create a unified community. The main purpose of an effective policy of demobilization, according to Vargas and Rubio (2003), makes necessary the creation of opportunities and skills development, active participation of demobilized people in social policies, support Colombia's financial relations and international cooperation for productivity projects, a strategy towards the safe and productive region, assistance in training and self-support processes, and finally a close relationship between the reintegration programme and productive projects for the demobilized people and Colombia's Unit for Comprehensive Attention and Reparation of Victims. The majority of demobilized people are young people between the ages of 21 and 30, that is, in productive age, who are part of the economically active population, they are willing to train and carry out entrepreneurship projects to continue their process of reintegration and improve their quality of life, accompanied by governments, institutions and the international community. Entrepreneurship not only generates the expansion of the entrepreneurial base, considering an increase in employment, investment and economic development, but also social progress reflected in the improvement of the quality of life among the inhabitants. It provides an opportunity to play a productive and valued role in the society, fostering its acceptance and permanence within the community. The multi-active association of demobilized people from Tallambí is sustained with their own resources but few credits or microcredits; this would mean that people do not apply for a loan offered by funding organizations or cooperative sectors. This situation might be because of the poor promotion of these entities in the region or unawareness of the processes required, therefore, it is important to inform people from Tallambí about accessing capital and get funded.

\section{References}

1. Departamento Administrativo Nacional de Estadística (DANE) [Internet]. [citado 2 oct 2017]. Proyección de población en Colombia. Available https://www.dane.gov.co/files/investigaciones/poblacion/proyepo bla06_20/ProyeccionMunicipios2005_2020.xls.

2. Anggadwita G, Dhewanto W. Women's Entrepreneurial intentions in micro and small enterprises (MSEs) in Indonesia: The influence of environmental factors on perceived behavioral control. J Adm Bus Stud. 2015;1(1):1-7. doi:10.20474/jabs-1.1.1

3. Musa, G. The role of accounting education towards the development of small and medium enterprises in Jigawa State. International Journal of Business and Administrative Studies. 2016; 2(4): 96-102.

4. Intriago R, Gortaire Amézcua R, Bravo E, O’Connell $\mathrm{C}$. Agroecology in Ecuador: historical processes, achievements, and challenges. Agroecol Sustain Food Syst. 2017;41(3-4):311-328. doi:10.1080/21683565.2017.1284174

5. Schilhab T, Gerlach Ch. Connections in Action - Bridging Implicit and Explicit Domains. En Hoffmeyer J. editor. A Legacy for Living Systems 2da ed. Copenhague: Springer; 2008, p. 135144 Doi 10.1007/978-1-4020-6706-8_9.

6. Cortés Sánchez J. [Internet]. [citado 10 sep 2018]. Emprendimiento, instituciones y construcción de paz. Universidad del Rosario. Available in: https://www.urosario.edu.co/Escuelaadministracion/Documentos/investigacion/proyectos/Emprendimi ento-Instituciones-2016.pdf

7. Farfán Orozco M., Alzate Pineda C. Factores motivacionales de la población en proceso de reintegración social y económica para su ingreso y permanencia en el sistema educativo, área metropolitana de Risaralda durante el año 2010: estudio cualitativo realizado con participantes del proceso de reintegración en el área metropolitana de Risaralda. Manizales:
Centro de Estudios Avanzados en Niñez y Juventud [Maestría] Alianza de la Universidad de Manizales y el Centro Internacional de Educación y Desarrollo Humano (CINDE); 2011. Available in: https://repository.cinde.org.co/bitstream/handle/20.500.11907/43 2/AlzateClaudiaMonica2011.pdf?sequence=1\&isAllowed=y.

8. KienyKe [Internet]. [citado $10 \mathrm{feb}$ 2019]. La palabra es lo que vale en Tallambí, Nariño [Mensaje en un blog]. Available in https://www.kienyke.com/historias/tallambi-narino-dialogo-pazfarc

9. Ibarra Mares A. Emprendimiento para la creación de empresas con responsabilidad social. Medellín; 2014 Available in: http://www.eumed.net/libros-gratis/2014/1363/habilidadesemprendedor.html

10. Varela R. Innovación empresarial. Arte y ciencia en la creación de empresas. Bogotá: Pearson Prentice Hall; 2008. 